DOI https://doi.org/10.36059/978-966-397-225-1-9

\title{
CONTEMPORARY BANDURA PERFORMANCE IN THE CONTEXT OF THE FOLK ART ACADEMISATION
}

\section{Broiako Nadiia}

\section{INTRODUCTION}

Bandura art is deeply rooted in the traditions of Ukrainian national folk melodies and is an essential component of national identity. The history of the bandura performance study goes two centuries back and covers kobza and bandura style transformations. Today, the stylistic variations of bandura art continue, and their analysis and study of the overall picture are of considerable interest for scientific understanding of the regularities of development of contemporary Ukrainian performing arts.

Bandura performance occupies one of the essential positions in the modern Ukrainian space but it is not a constant: in the process of evolution of kobza and bandura music the functions of performers, the techniques of playing kobza and bandura have changed significantly, the musical language has been improved and modified. The function of the instrument has undergone various metamorphoses - from a solo accompanying instrument in the kobzar and old-world musical traditions to participation in different bands on the modern stage. Both the repertoire and the performance provided changes in the genre and style. Bandura art is developing actively today, and this process covers all its components: education, instruments, scientific and methodological achievements, composition, improvisation, arrangement and interpretation, performance.

Describing this movement in general terms, we can outline its two main components: the evolution of traditional elements of the kobza and bandura tradition, and its interactions with the spheres of academic musical art.

\section{Bandura Art in the Scientific Discourse of the Twentieth Century}

Ukrainian bandura art of the end of the 20th and the beginning of the 21 st century attracts close attention of researchers due to the growing interest of the art community and listeners both to the expansion of its genre and stylistic, tone painting and interpretive possibilities. At the same time, a profound disclosure of the essence of bandura performance requires an 
appeal to its folklore origins. Hnat Khotkevych noted that the origins of "kobza, (bandura) art are in the folklore line that came from folk singers" ..

The kobza and bandura tradition is a unique phenomenon and an invaluable treasure of the Ukrainian people in which national culture, deep traditions, sacred worldview, musical ethos are represented. The study of kobza art, recording of texts, and then notation of melodies of duma, songs, chants and psalms began in the 19th century and lasted until the beginning of the 20th century. Writers, artists, musicians, scientists and amateurs who were in love with folk culture took an active part in this process (V. Hnatiuk, M. Hrinchenko, K Hrushevska, D. Demutskyi, P. Zhytetskyi, K. Kvitka, F. Kolessa, P. Kulish, M. Lysenko, B. Luhovskyi, P. Martynovych, D. Revutskyi, O. Rusov, O. Slaston, M. Speranskyi, M. Sumtsov, O. Famintsyn, H. Khotkevych, P. Chubynskyi, etc.).

The researches and practical mastery of the kobza and lira tradition have been further developed since the second half of the 20th century in the researches and work of historians, ethnomusicologists, folklorists and performers (M. Budnyk, S. Hrytsa, A. Horniatkevych, B. Kyrdan, N. Kononenko, V. Kushpet, M. Lavrov, V. Mishalov, V. Noll, A. Omelchenko, H. Tkachenko, M. Tovkailo, M. Khai, K. Cheremskyi, etc.).

The history and theory issue of academic bandura performance are widely represented in the works of modern musicologists ( $\mathrm{N}$. Broiako, O. Vavryk-Dubas, I. Dmytruk, V. Dutchak, I. Lisniak, L. Mandziuk, I. Mokrohuz, N. Morozevych, M. Semeniuk, N. Suprun, N. Cherenetska and others). The artistic, spiritual and philosophical, and communicative activities of kobzars were recorded in written and printed sources of Europe during the 15th-19th centuries. The most thorough and profound researches of kobza and bandura authentic performance in Ukrainian musicology was conducted by Sofia Hrytsa. The outstanding ethnomusicologist, folklorist and art critic who has been researching the activities of kobzars and lirnyky and the genesis of the Ukrainian duma epos for decades emphasises that the toponymy, vocabulary of dumas, their music, principles of training and life of folk professionals (kobzars and lirnyky) indicates to the South-Eastern vector of development of duma, to the connection with the South Slavic and anti-Turkish epos, youth and hajduk songs. As for the musical form, there is a quantitative recitative and the dominance of the principle of formality, chromatism of thinking mode and folk and professional performance with Eastern maqam in its development. The dumas and their performers remind

1 Khotkevych H. (2009) Bandura ta yii repertuar [Bandura and its repertoire] (ed. Mishalov V.). Toronto ; Kharkiv: The Hnat Khotkevych Foundation for National Cultural Initiatives, p. 20. 
of the remnants of Scythian and Iranian influences in Ukrainian culture (Kozak Mamai playing the kobza) ${ }^{2}$.

The author emphasises the plot and stylistic unity and integrity of the genre of the duma, imbued with a single national idea, despite the long period of statelessness of the Ukrainian ethnos in the past, imbalance, fractality of its state-building processes. The researcher claims that duma, as "a genre of Ukrainian epics with remnants of ancient syncretism, as well as the related to it art of kobza and bandura players and lirnyky, is quite original in the field of the verbal and poetic and musical style of the Ukrainian Renaissance. Therefore, it is no coincidence that dumas are called a diamond in the crown of the freedom-loving Ukrainian people"3.

The flowering of kobza and bandura art, as well as the duma genre, dates back to the 16th-17th centuries. The author of the monograph Ukrainian Duma and Song in the World, Ukrainian writer, folklorist, historian, critic and cultural critic H. Nudha notes: "According to Ya. Shtellin's words, the Ukrainian bandura was well-known both in terms of its structure and musical capabilities in Germany in the middle of the 17th century, and therefore, the bandura players and the songs and dumas they sang were also known"

Analysing the German written sources of the 18th century about the Ukrainian musical culture of that period, the researcher finds proof that kobzars were "presented to the world as virtuosos and bearers of high musical culture" . Using their singing, Johann Gottlieb Georgi Beschreibung des Russischen Reiches published the samples of Ukrainian melodies Metelytsa and Kozachok which the bandurists played and danced themselves, according to Ya. Shtellin, holding a glass of wine on the bandura. This dance was published in the German Piano Textbook, 1789.

Describing the performance features of duma accompanying, A. Rudnytskyi remarks: "the bandura accompaniment was quite primitive

${ }^{2}$ Hrytsa S., Ivanytskyi A., Filatova, A. (comps.) (2007) Ukrainski narodni dumy [Ukrainian folk dumas] (ed. Skrypnyk H.). Kyiv: Rylsky Institute of Art Studies, Folklore and Ethnology of National Academy of Sciences Ukraine.

3 Hrytsa S. (2000) Folklor u prostori ta chasi [Folklore in space and time] (ed. Smoliak O. S.). Ternopil: Aston, p. 105.

${ }^{4}$ Nudha H. (1998) Ukrainska duma i pisnia $v$ sviti [Ukrainian thought and song in the world] (Vol. 2). Lviv: The Ethnology Institute of National Academy of Sciences of Ukraine, p. 14.

${ }^{5}$ Nudha H. (1998) Ukrainska duma i pisnia $v$ sviti [Ukrainian thought and song in the world] (Vol. 2). Lviv: The Ethnology Institute of National Academy of Sciences of Ukraine, p. 14. 
and uninteresting. Usually, only two incomplete chords of the corresponding tonic and dominant were used"

However, the author notes that although this accompaniment was of little interest from a musical point of view, it influenced the formation of the general, original and archaic character of these songs greatly. In the second half of the 18th century, the bandura lost its significance gradually, and the lira became an accompanying instrument for dumas.

The fact that the kobza tradition, as well as the entire heroic epic, experienced its culmination in the 18th century is indicated by numerous researchers - S. Hrytsa, D. Revutskyi, K. Kvitka, F. Kolessa. A significant scientific contribution to the study of kobza art as an original traditional vocal and the instrumental genre was made by the famous bandura and kobza player, lirnyk and ethnomusicologist, teacher Volodymyr Kushpet in numerous works. Based on the foundation of spiritual and aesthetic values and creative achievements of traditional kobza art, the famous modern performer mastered the basics of the ancient tradition both practically and theoretically on reconstructed kobza instruments and in his search turned to the activities and work of the founders of modern kobza art as a concert genre - Hnat Khotkevych, Vasylm Yemets, Zinovii Shtokalko and their followers - Heorhii Tkachenko and Mykola Budnyk. The acquired knowledge made the artist comprehend the activities of travelling musicians from a new perspective, realise their mission, immerse himself in the philosophy of their life and the peculiarities of music-making. V. Kushpet studied theoretically and applied the old-world system of the kobza and lira singing and play found an original way to revive the disappeared tradition musical and language improvisation, that, in his opinion, "will return techniques of live formation, as opposed to primitive memorisation of samples of duma works to modern musical performance" 7 .

V. Kushpet, mastering skillfully the techniques and methods of improvisation in the sing and play, concluded that the reconstruction of the old-world system of performance of kobza tradition is possible only through the interpretation of the duma genre. The researcher found out that the authentic kobza and bandura system of mastering the sing and play is built on a unique principle. The works performed by kobzars had established forms, which each master created using certain modes-templates: musical

\footnotetext{
${ }^{6}$ Rudnytskyi A. (1963) Ukrainska muzyka [Ukrainian music]. Munich: Dniprova khvylia, p. 31.

${ }_{7}$ Kushpet V. (2007) Startsivstvo: mandrivni spivtsi-muzykanty v Ukraini (XIX pochatok XX stolittia) [Old age: itinerant singers-musicians in Ukraine (XIX - early XX century)]. Kyiv: Tempora, p. 387.
} 
and fret in the sing and play and figurative and pictorial in the creation of the plot. The heterogeneity of the musical and mode material of dumas, certified by F. Kolessa, K. Kvitka, S. Hrytsa explains, in the author's opinion, by different ways of forming of this genre - "Cossack psalms" had a more diatonic statement of the melody, as they were formed under the influence of religious services, and the "slavery crying" came from the people's laments, which in their turn absorbed a distinctive ethnic scales.

Exploring the transformation of folk art of the 20th century, I. Zemtsovskyi notes: "the artistic creativity is becoming art for the people more and more and not only art. With the overcoming of the age-old traditions, the modern folk art is becoming a separate art from work area of the actual artistic activity more and more, which goes to the future in a fundamentally different way. There is a way of professionalism ${ }^{8}$.

The prominent ethnomusicologist, researcher of kobza art S. Hrytsa notes the typology of these transformational processes of the 20th century. Having carried out a systematic, multilevel analysis of folk art in the context of the environment of its existence, the researcher identified constant and variable features of the work, revealed the cause-effect relations between the artistic product and objective conditions affecting its nature and evolution, revealed the dynamics and structural functions of folklore in different types of environment. Noting the influence of the urban environment on the differentiation of communicative links according to C. Shannon's scheme, "creator - performer - recipient", Sofiia Hrytsa finds the increase in demand for music product by the recipient outside the closed environment and, consequently, the increase of the performer influence. The author concludes: "this circumstance changes the forms of social circulation of folklore, transforms it from art for oneself to art for others" "..

It should be noted that the beginning of the 20th century is marked by the attraction of the bandura players to the latest concert forms in the works of such performers as H. Bilohub, D. Honta, V. Yemets, I. KuchuhuraKucherenko, M. Levytskyi, K. Misevych, Yu. Sinhalevych, M. Teliha, H. Khotkevych, D. Shcherbyna and others. It is namely during this period that interpenetration, diffusion, interaction of the musical folklore layer and the concert and academic genre appeared, and the transition from folk professionalism to academic professionalism took place. According to S. Hrytsa's opinion: "The rise of great music is a sign of the polarisation of

8 Zemtsovskiy I. (1977) Narodnaya muzyka i sovremennost' [Folk music and modernity]. Sovremennost' i fol'klor [Modernity and folklore]. Moscow: Muzyka, p. 74.

9 Hrytsa S. (2000) Folklor u prostori ta chasi [Folklore in space and time] (ed. Smoliak O. S.). Ternopil: Aston, p. 58. 
society and the polarisation of art itself, the distance is growing and the relationship between genius (author) and folk tradition is straining. Thus, there is a clear difference between the state of "childhood" of human activity, which is folklore, and the state of "maturity", which is a professional art, and hence there is an adequate assessment of its social function" $"$.

Kobzar art and old-world bandura music-making of the 19th century grew and functioned in their own educational system. There was training with the priests and vyzvilka (final examination) by the members of the workshop. In the 20th century, bandura performance entered the wellorganised system of music education: music schools - studios, and music societies - music schools - music institutes - conservatories - music academies - universities. The tradition of oral, unwritten passing of the works of folk epics singers yields to notation and written passing of the bandura repertoire. The change of the epoch, the transition to the postmodern society of the 20th century lead to a change in the forms of the functioning of kobza and bandura art.

Modern bandura performance is the result of the evolution of the structure and functioning of kobzardom and old-world bandura music. Having passed the stages of folk art, which are recorded in the duma epos of authentic bearers of the kobza and lira tradition (S. Veselyi, A. Hreben, V. Honchar, F. Kushneryk, N. Kolisnyk, Ye. Movchan, A. Parfyrenko, H. Tkachenko, O. Chupryna etc.), the transformation of bandura players of the concert type with a significant part of the reconstruction of the duma epos and song folklore in the repertoire (M. Budnyk, V. Yemets, V. Kushpet, V. Mishalov, M. Teliha, M. Tovkailo, H. Khotkevych, K. Cheremskyi, Z. Shtokalko and others) today bandura performance is represented by the work of bandura players who position themselves as academic musicians (O. Herasymenko, R. Hrynkiv, D. Hubiak, T. Lazurkevych, K. Novytskyi, O. Sozanskyi and others).

The well-known Ukrainian bandurist, researcher of the issues of musical Ukrainian Studies, folk art, bandura art of Ukraine and the diaspora V. Dutchak, studying the evolution of bandura art, notes: "The turn of the 19th-20th centuries marked the beginning of a new stage in the development of kobzar tradition, which was marked by changes in instruments, repertoire, performing styles, as well as the appearance of scientific works on the history of the bandura, textbooks, manuals, repertoire collections, etc. At the origins of this new stage were prominent Ukrainian artists Mykola Lysenko and Hnat Khotkevych, who played an important role in the academic

${ }^{10}$ Hrytsa S. (2000) Folklor u prostori ta chasi [Folklore in space and time] (ed. Smoliak O. S.). Ternopil: Aston, p. 64. 
formation of the bandura in the field of bandura art concerning instruments, recording and popularisation of repertoire genres, performance, written education, history, theory and techniques of playing" $"$.

The figure of Renaissance scale(avant-garde writer, oncologist, bandurist, folklorist, author of the original bandura technique; researcher and representative of the ancient archaic traditions of the Ukrainian epos (bylinas, dumas), heir to the deep foundations of the kobzar worldview) Zinovii Shtokalko noted: "With its special path of development and artistic characteristics, Kobzardom, growing into artistic folklore, grows far beyond it at the same time" 12 .

However summarising modern art history scientific views, M. Khai states that "folklore is not art at all, but a folk art practice, the function of which is not artificial, refined (synthetic), but pragmatically defined, natural, syncretic way of artistic understanding of reality" ${ }^{\prime 3}$.

The researcher of the history of Ukrainian music Antin Rudnytsky also emphasises that there is a connection between folk music and Ukrainian artistic, that is, original ("composer") music: "We are talking about works that use a folk song either in its modified form or as a material for the creative ingenuity of the composer, to create folk music or such one that it has its atmosphere and colouring" ${ }^{\prime 14}$.

Analysing the ways and methods of bandura performance academisation, V. Dutchak states that "during the 20th - the beginning of the 21 st century on the basis of continuity of national ideological and aesthetic positions and traditions of folk and instrumental music-making, a collective artistic concept that defined the unambiguous essence of bandura art in the world, as a representative of Ukrainian music, instruments, performance forms, was formed" $"$.

${ }^{11}$ Dutchak V. (2013) Bandurne mystetstvo ukrainskoho zarubizhzhia XX-pochatku XXI stolittia [Bandura Art of Ukrainian Abroad of XX-Early XXI Century]. IvanoFrankivsk: Foliant, p. 65.

${ }^{12}$ Shtokalko Z. (1992) Kobzarskyi pidruchnyk [Kobzar textbook] (ed. Horniatkevych A.). Edmonton ; Kyiv: Canadian Institute of Ukrainian Studie, p. 1.

${ }^{13}$ Khai M. (2015) Mykola Budnyk i kobzarstvo [Mykola Budnyk and kobzarism]. Lviv: Astorliabiia, p. 13.

${ }^{14}$ Rudnytskyi A. (1963) Ukrainska muzyka [Ukrainian music]. Munich: Dniprova khvylia, p. 41.

${ }^{15}$ Dutchak V. (2018) Tvorcha i naukova diialnist Andriia Horniatkevycha (Kanada) v konteksti rozvytku bandurnoho mystetstva Ukrainy ta diaspory [Artistic and scientific activity of Andrij Hornjatkevyč (Canada) in the context of bandura art development in Ukraine and among diaspora]. Bulletin of Kyiv National University of Culture and Arts. Series in Musical Art, vol. 1, p. 107. https://doi.org/10.31866/2616-7581.2.2018.153383 
The study of academisation, as a continuous process of artistic creativity evolution, reveals its commonality with the phenomenon of globalisation. So, the academisation of musical art and bandura performance as its component is the result of an objective social historically determined law of globalisation, which means a natural process of integration of fragmented sociocultural phenomena into a unified system, where academisation is identified with the universal language of music.

Although the processes of academisation of folk instruments were discovered and became the subject of scientific research in the last third of the 20th century, their regularities originated and began to function in the era of archaic folklore. The evolution of musical consciousness is clearly observed in the development of artistic and expressive means of musical language, rethinking of the artistic meaning of rhythm, harmony, dynamics, timbre, and other tone painting means of music. Thus, it can be claimed that folklore (kobzardom and authentic bandura playing) is the language of ethnic communication of a local group, and academic art (modern bandura performance) is the language of interethnic communication of the global world.

However, in the academisation of bandura playing of folk music there are not only positive but also negative tendencies, such as the shift of the functions of performing art from communicative to representative one; the unification of musical language and activity (tendency to typification, standardisation, thinking by cliches); directing the efforts of academic performance for searching an ideal interpretation led to the supplanting of the listener (recipient) to the background. The decrease in the need for communication with live art is observed not only among performers but also among consumers of musical art (the transition of modern performing forms into a virtual media space of communication between the creator and the recipient). These trends lead to the transformation of academic art into elitist one, that is evidenced by the half-filled academic philharmonic halls. The reasons for elitarisation are related to the different rates of emergence of innovations in the musical language and their socialisation, adaptation to the real conditions of coexistence of the musical product and the audience. That is, the emergence of innovations outpaces the rate of their socialisation. This phenomenon is not new, and in the history of music there are widely known examples when the recognition of a composer's work or the emergence of a new musical style happened too late - their musical language did not have time to socialise, to become a communicator.

The process of academisation has raised several questions and criticisms about the ways of development of modern bandura art. In the middle of the 20th century, Z. Shtokalko had a negative attitude to the attempts to make bandura a universal instrument, calling this process an "unfortunate 
misunderstanding" and explaining it by the lack of information about the traditions of this performance type. Today, the ethnomusicologist M. Khai has launched a broad discussion about the expediency of functioning of academic bandura performance at various scientific, artistic, cultural media platforms and questions the established terms and concepts of "bandura studies", "academic performance", calling the modern dominant instrument as "quasi-bandura derivative". The researcher claims: "The Bandurist Gang continues to rape folk authenticity and its scientific reconstruction with impunity, finally displacing them from the specific and scientific niche and, more broadly, the performing environment"16.

Thus, along with the significant artistic achievements of modern performers of the academic bandura genre in their activities, a number of trends that led to the crisis of the favourite folk genre are observed: deep stratification of bandura art in two directions - folklore and authentic (S. Zakharets, T. Kompanichenko, V. Kushpet, V. Mishalov, M. Tovkailo, K. Cheremskyi, etc.) and academic one (O. Herasymenko, R. Hrynkiv, L. Dediukh, V. Yesypok, P. Chukhrai, etc.); aggravation of the relationship between the author and the recipient of the artistic product - composers and performers incline to the elitist type of creativity more and more (R. Hrynkiv, V. Zubytskyi, V. Pavlikovskyi) while listeners expect a recognizable musical language; the chromatisation of bandura (due to the introduction of an additional string series) provided an opportunity for the interpretation of works of world classics (concerts, sonatas, suites, etc.), but led to the displacement of folk music, which is diatonic in nature; discrepancy of modern music education with the requirements of the stakeholders - today the market needs not narrow specialists, but universal musicians who are able to be not only brilliant performers, but also multiinstrumentalists, conductors, arrangers, research theorists, managers of the cultural and artistic industry.

One of the key problems that the modern "academician" bandura players have is the problem of concert repertoire. The official status of the "folk academic instrument" involves the appeal of performers to broad layers of folk music. And although the technical and performing parameters of the modified chromatic bandura with a system of levers and switches allow performing the best examples of reconstruction of musical folklore in the

${ }^{16}$ Khai M. (2016) Hibrydna terminolohiia v ukrainskomu «banduro»-kobzaroznavstvi [Hybrid terminology in Ukrainian "bandura" - Hybrid terminology in Ukrainian "bandura" - kobza studies]. Proceedings of the Tradytsiina bandura: mynule, suchasne, maibutnie: Internetional Scientific and Practical Conference (Kyiv, Ukraine, June 18-19, 2016). Kyiv: Ivan Honchar Museum, p. 169. 
conditions of solo and ensemble music-making, musicians are brought up (especially in higher school) on high samples of academic music by classical composers (J. Bach, D. Bortnianskyi, A. Vivaldi, N. Paganini, D. Scarlatti, P. Tchaikovsky, etc.). Due to low interest and unwillingness to study the specifics of bandura sound production, the range of modern authors who write for the bandura is insignificant (I. Haidenko, O. Herasymenko, R. Hrynkiv, D. Hubiak, V. Vlasov, V. Zubytskyi, R. Lisova, L. Makukha, H. Matviiv). At this time, traditional folk music is supplanted on the repertoire periphery and, as a rule, represented by arrangements of Ukrainian folk songs, while the performance of reconstructions of the duma epos occupies a prominent place in the concert repertoire of the individual bandura players (D. Hubiak, O. Sozanskyi, T. Lazurkevych, V. Mishalov, T. Kompanichenko).

In his research, the well-known modern Ukrainian bandura and kobza player Volodymyr Yesypok also connects the wide representation of classical music in the concert repertoire of the bandura players with the modification of the instrument, pointing to the inadmissibility of performing opera arias accompanied by the bandura, which smacks of provincialism and peasantry. The researcher of kobzardom warns: "A kobzar has the right to perform some. Beethoven and D. Bortnianskyi, P. Tchaikovsky and B. Liatoshynskyi's works, but a listener expects national deep spirit of folk song and duma by a kobzar, and he can listen to the classics at other instruments performance" $" 17$.

B. Yaremko also assesses the state of hypertrophied academisation of the modern bandura repertoire critically: "Ukraine, entering the third millennium, can be proud of the well-trained bandurists-performers of works by Bach, Mozart, Handel and other classics that have never written for the bandura, but still does not hear... kobzars-singers of the traditional kobza repertoire...Such great distortions have occurred in official music institutions in connection with the displacement of the study and research of folk traditional musical instruments and their music from academic research institutions and educational institutions of Ukraine and focus exceptionally on musical instruments of the improved type that meet the performing aesthetics of European composer music ${ }^{18}$.

17 Yesypok V. (2017) Suchasne kobzarstvo [Contemporary kobza art]. Young Scientist, no 7(47), p. 73.

18 Yaremko B. (2003) Etnoinsturmentoznavstvo [Ethnoinstrumentology]. Rivne: Rivne State University for the Humanities, p. 161. 


\section{Trendy Bandura Performance}

The consideration of the specifics of bandura academic performance, its interaction with deep kobza traditions, the activities of modern professional musicians allow identifying the essence and dynamics of changes taking place in the modern artistic context.

In the process of performing arts development, the modification of musical instruments takes place in connection with the genre and style changes of the musical material. In all known spheres of music-making, these are namely the changes in the musical language that create new requirements for the instruments, which causes the rapid development of instrument design. The modern field of music has given a new impulse to the development of instrumental and tone painting innovations of contemporary bandura performance. There is no doubt that new spheres of musical reality and instruments interact and have a mutual influence. Composers turn to the samples of folk music, process, rethink creatively and transform it constantly. At the same time, the reverse process of folk processing of the original author's work, better known as folklorisation, takes place. There is the same situation with instruments: individual composers involve folk instruments in the field of academic orchestral music (mainly percussion and noise instruments, aerophones), and in traditional music, basic academic instruments are established (clarinet, trumpet, French horn, trombone). At the same time, a group of instruments with binary status in both traditional and academic musical spheres - bandura, violin, guitar - is distinguished.

At the turn of the 20th-21st centuries in the instrumental bandura academic environment, a tendency to interact with pop-jazz and rock culture is observed, which leads to both an intensive search for new tone making techniques and an expansion of the timbre palette of the instrument, and a return to the authentic sound ideal through the revival of traditional methods of bandura sound production (flageolet, glissando, slide, cluster).

Bandura art of this period is characterised not only by a return to the traditional repertoire structure and the revival of authentic kobza playing techniques but also by rethinking a number of important elements of the music system. One of the markers of such changes in modern bandura performance is the intensive search for new tone painting elements, the colourfulness of sound, sonorism. This was facilitated by the chromatisation of the instrument and the expansion of bandura musical language and the use of dissonances in composer creativity and arrangements, the formation of new chords and elements of harmony, the appeal to timbre imitation. The most important factor that determines the picturesqueness, the colourfulness of the sound of a musical work on the instrument is its timbre characteristics. 
Thus, the importance of timbre in modern bandura interpretation increases. Among all elements, the sonorous elements acquire a significant value.

The modern bandura players tend to search for new means of expression, colours and performing techniques. A flageolet on the bandura is a way of forming an octave overtone. Each string, which oscillates along its entire length freely, generates a certain sound - it is called the main one. But, as it's known, an exciting string oscillates not only entirely, but at the same time partially (halves, thirds, quarters, etc.), and each part is a source of a partial tone - overtone. If one touches a string with a finger easily at the point that divides it, for example, into two parts and make it oscillate simultaneously, the string will acquire a special movement: it will oscillate in the corresponding parts, not entirely. The sound produced in this way has a special timbre, that reminds the sound of the French pipe-like instrument "flageolet", from which it has got its name. The flageolets are divided into two types: natural and artificial. The artificial ones are formed on a string pressed against the neck (inherent in "neck" instruments - plucked string ones, domra, balalaika, etc.). The natural ones are on an open note. The bandura specifics allows performing natural flageolets. Theoretically, a string can be divided into any number of vibrating parts, but in practice, this possibility is quite limited. Octave flageolets sound best on the bandura, and therefore they are mostly used. To make the sound of the flageolet quite clear and transparent, the exciting touch of the tip should be light, with minimal use of finger weight.

Glissando on the bandura is a special technical way of connected and connected-separate production of sounds in a row. Glissando is played by sliding in the specified range in a monophonic, interval and chord texture. The slide is a series of consecutive strokes combined with a directional movement. While performing, depending on the artistic tasks, the various types of diatonic (on the main and auxiliary courses of strings), chromatic (on the line of intersection of the main and auxiliary courses), combined (the combination of the alternating performance of diatonic and chromatic, nontempered glissando in one line) glissando are widely used, the emotional and semantic nuance of which depends on the direction of movement (ascending, descending, counter, polyline), tempo, dynamics, articulation colouring. Traditionally, glissando on the bandura is a kind of connected (legato) playing, which is provided by the "overlapping" of the previous tone to the next as a result of the natural vibration of the excited strings. The modern performers and composers expand the colouristic and figurative and technical and performing possibilities of the bandura boldly. The result of such searches is the introduction of another type of glissando into performing practice - we propose to call it connected-separate. The method 
of string excitation here is the same as in the legate glissando. But if the legato connection of sounds occurs due to a sound "overlapping" in a traditional glissando, then in a connected-separate one, the vibrating string (at the moment of excitation of the next one) is suppressed by a tip of a free finger that is not involved in the process of sound production. The need for tip damping determines the only possible direction of the connected-separate glissando - descending. In terms of timbre colouring, the connected-separate glissando resembles a pizzicato - the characteristic simultaneous bifunctionality of the fingers (excitation and damping) causes them to be especially close to the string scale with support when hitting by the tip, which causes less deformation of the string and forms a softer sound, which is poor in high overtones.

The sonorous and colour palette of the bandura has been significantly enriched by expanding the excitation zone of the strings. The diatonic glissandos, formed near (below) the pegs, near the support, and untempered, performed below the support and between the rows of pegs, are widely used. In modern instrumental literature, a cluster is used for the bandura - a chromatic second polyphony that fills a certain interval space completely. To perform a cluster on the bandura, an unconventional method is used - the strings are excited in a given range by the blow of an open palm, or the edge of the palm, on the line of crossed strings.

It is namely due to the new application of traditional methods of sound production and modern sonorous-colouristic techniques that the internal renewal of bandura culture and its further development is possible ${ }^{19}$. One of the brightest representatives of modern performance is a well-known bandura player in Ukraine and abroad - Roman Hrynkiv. He is an innovator and has conducted searches in the direction of constructive modification of both the modern Kyiv and Chernihiv bandura and the electric bandura with an aluminium body. Besides, he is an author of interesting and original masterpieces. His creative work includes joint concerts with the worldfamous guitarist Al Di Meola, which has promoted the Ukrainian national culture, instruments outside Ukraine.

According to R. Hrynkiv, the modifications he made in the bandura design are the result of the evolution of the instrument. "And I consider that we are witnessing the evolution of the instrument that has previously acquired new interesting features in the course of its development, as it has happened with

19 Broiako N. (2015) Aktualni problemy suchasnoho muzychnoho vykonavstva [Actual problems of modern musical performance]. Bulletin of Mariupol State University. Series: Philosophy, culture studies, sociology, vol. 9., pp. 33-38. 
other instruments, such as violin, harp, cymbals..."20. The performer testifies himself that the modifications in the instrument design and his composer activities for the bandura are interrelated factors. As Hrynkiv points out: "The bandura is played only by someone who really loves it. One can't make money on it (the conservatory replenishes the ranks of the unemployed), but the attention to this instrument still does not decrease. Only the bandura requirements change. For example, my students don't want to play educational "naphthalene", they prefer works which they can perform on stage",21.

R. Hrynkiv, as a performer, is connected with many artistic musical directions. His creative work includes collaboration with Ukrainian contemporary composers, first of all, Ivan Taranenko, the director of the festival of contemporary and academic music "Farbotony" (Kaniv). Taranenko's creative search is indissolubly connected with academic music, jazz, and even Worldmusic. It was namely in the last two directions that the collaboration with the famous bandura player took place. This is what I. Taranenko tells about his collaboration with R. Hrynkiv: "In joint improvisations, we really feel each other in our bones... Roman Hrynkiv is a unique person. He knows how to make something out of nothing: for example, to take one note and weave a whole work out of it. He has made the bandura a universal instrument. Roman is in constant search, does not allow stopping in one place, encourages to progress further",22.

However, of course, moving from the sphere of academic performance to the sphere of pop music inevitably contributes to commercialisation. R. Hrynkiv states: "Creativity, directed only to earn money, ceases to be creativity: it is employment, business. And in business, there is a strict law: worshipping the golden calf. Show business principles are dirty pool, killing floor, the battle is to the strong (we do not mean a talent), there is no third

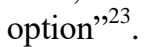

${ }^{20}$ Koskin V. Roman Hrynkiv: "Pro banduru maie znaty ves svit" [Roman Grinkiv: "The whole world should know about the bandura"]. Retrieved from: http://www.vox.com.ua/data/osnovy/2007/04/27/roman-grynkiv-pro-banduru-maye-znatyves-svit.html (accessed 5 October 2020).

${ }^{21}$ Koskin V. Roman Hrynkiv: "Pro banduru maie znaty ves svit" [Roman Grinkiv: "The whole world should know about the bandura"]. Retrieved from: http://www.vox.com.ua/data/osnovy/2007/04/27/roman-grynkiv-pro-banduru-maye-znatyves-svit.html (accessed 5 October 2020).

${ }^{22}$ Yusypei R. (2006) "Farbotony" ["Pharbotones"]. Den [Day], no 118. Retrieved from: https://day.kyiv.ua/uk/article/kultura/farbotoni (accessed 5 October 2020).

${ }^{23}$ Koskin V. Roman Hrynkiv: "Pro banduru maie znaty ves svit" [Roman Grinkiv: "The whole world should know about the bandura"]. Retrieved from: http://www.vox.com.ua/data/osnovy/2007/04/27/roman-grynkiv-pro-banduru-maye-znatyves-svit.html (accessed 5 October 2020). 
Along with staging in the virtual media space and the commercialisation of the bandura genre, there is also a scientific search to preserve and continue the reconstruction of the authentic bandura performance.

A significant contribution to the preservation and reconstruction of authentic old-world bandura performance was made by a prominent Australian-Canadian bandura player of Ukrainian origin, ethnomusicologist, composer, arranger, conductor, scientist and researcher and promoter of kobzardom in the world Victor Mishalov. The formation of the artist's spiritual and ideological system, his musical tastes and preferences, except for his family, in different periods of life, was influenced by prominent, and sometimes legendary, figures of Ukrainian culture in Ukraine and abroad. They are Sofiia Hrytsa, Leonid Haidamaka, Petro Honcharenko, Petro Deriazhnyi, Vasyl Yemets, Petro and Hryhorii Kytasti, Volodymyr Kolesnyk, Andrii Omelchenko, Heorhii Tkachenko, Mykhailo Khai and others.

It was namely Victor Mishalov who was one of the first in Ukrainian musicology (along with Nadiia Suprun, Petro and Konstantyn Cheremsky) to study the compositional, ethnoorganological, methodological and musicological heritage of Hnat Khotkevych systematically. He collected more than seventy musical manuscripts and edited a significant part of them, introducing them into the modern concert repertoire. He wrote introductory scientific articles and contributed to the editing and preparation of the corpus of works (H. Hk.)for publication, among them are Textbook of Bandura playing, the Ukrainian Musical Instruments, Bandura and Its Options, Bandura and Its Repertoire, Bandura and Its Construction, Music Pieces for the Kharkiv Bandura, etc.

The real event in bandura studies was the publication of V. Mishalov's monograph The Kharkiv Bandura. Cultural and Artistic Aspects of the Genesis and Development of Ukrainian Folk Instrument Performance ${ }^{24}$. For the first time in Ukrainian musicology, the author conducted a systematic study of the Kharkiv bandura, highlighting the phenomenon of this event in the context of world culture: on the basis of new little-known sources he revealed the genesis and features of the Kharkiv way of bandura playing; carried out research on the techniques of playing, repertoire and life of traditional folk kobzars of Slobozhanshchyna, on development of the phenomenon of stage kobzarism and the beginning of bandura playing, on the creation of the first academic courses of bandura playing in Kharkiv and professional kobzar bands. The researcher widely covered the sociocultural context of this period and the repressive measures that the Kharkiv school of bandura playing suffered from during political changes in Ukraine.

\footnotetext{
${ }^{24}$ Mishalov V. (2013) Kharkivska bandura [Kharkiv bandura]. Kharkiv : Savchuk O. O.
} 
Victor Mishalov is the only one among the performers who perfectly realised his creative ambitions both in the academic and the reconstructed old-world genre at the same time. He masters both Kyiv and Chernihiv and Kharkiv and Zynkiv performing schools perfectly, skillfully interprets both classics on academic banduras of various types (Chernihiv, Kharkiv and Lviv), and duma style, chants and psalms on the old-world bandura. The artist researches and collects kobza and bandura instruments carefully - his collection includes more than fifty unique samples of author's instruments of well-known designers (I. Skliar, H. Sniehirov, V. Vetsalo, Yu. Pryimak, Y. Mentei, V. Herasymenko) as well as instruments of unknown folk masters. The geography of V. Mishalov's touring life (Austria, Australia, England, Argentina, Holland, Canada, Mexico, New Zealand, United States, Latvia, Lithuania, Estonia, Poland, Russia, France) is extensive for both English-speaking and Ukrainian-speaking audiences. He recorded a number of concert programs (Bandura (1982), Bandura 2 (1985), Cossack songs (1987), The Classical Bandura (1989), The Best of Bandura 1992, Bandura Magoc 1997, Bandura Christmas Magic (1999), was one of the authors of the idea and co-organisers of the all-Ukrainian youth festival of contemporary song and popular music "Chervona Ruta" (1989). The extensiveness of Viktor Mishalov's creative personality and his contribution to the development and popularisation of bandura art cannot be covered in the proposed section and requires separate research.

Musical art is deeply incorporated in various spheres of human life, so the processes of finding new aesthetic perspectives, new emotional transformations, new sensory images are analyzed in Ukrainian scientific thought in different fields of science (Philosophy, Cultural Studies, Sociology, Psychology, Art Studies) by many scientists. In particular, T. Humeniuk notes that the state of culture in the 21 st century is defined by the concept of "new sincerity", in such new forms as reality shows, Internet blogs, that contributes to "the return to a person, to lyrical and confessional discourse" 25 .

\section{CONCLUSIONS}

The use of folklore sources as the main basis for the bandura repertoire formation becomes a new level of mastering the archaic musical culture and the opening of new opportunities for the development of bandura performance at the present stage. The analysis of modern bandura performance practice makes it possible to make certain generalisations: bandura performance is an

${ }^{25}$ Hrytsa S., Ivanytskyi A., Filatova, A. (comps.) (2007) Ukrainski narodni dumy [Ukrainian folk dumas] (ed. Skrypnyk H.). Kyiv: Rylsky Institute of Art Studies, Folklore and Ethnology of National Academy of Sciences Ukraine. 
integral part of the world musical context and is in the stream of leading artistic trends and methods of adjacent performing spheres (types); modern bandura players, demonstrating a high level of performance, reveal wide textural and timbre and colouring capabilities of the instrument; there are no mediation fields for highlighting the concert activities of the performers and popularisation of bandura performance in the world; the analysis of the process of bandura performance development revealed its movement in the direction of academisation and singled out the tendencies of this process; desyncretisation of musical thinking, language and creativity, which manifested in the modification of artistic means of expression and changes in the functioning of anthroposocial relations (the decline of the guild movement, the disappearance of the historical and heroic environment for the duma creation, the disappearance of the lebian language).

We have clarified the main stages of bandura academisation. There is instrument chromatisation, the introduction of the performing genre into the written musical tradition, the involvement of the bandura performance in professional composer activities, involvement in concert forms of musicmaking, modification of the instrument with obligatory preservation of timbre sound ideal.

The transition from untempered diatonic to the tempered chromatic scale, from oral to the written system of storage and passing of musical information, and, as a consequence - the expansion of figurative, intonation, stylistic spheres, deepening and complication of the content and forms of the performed works, creation of original repertoire and improvement of the instruments.

\section{SUMMARY}

This study is a fundamental research for the processes of Bandura performance development. Numerous scientific studies of the work of authentic and modern reconstructed kobzardom as one of the archaic, syncretic components of Ukrainian culture confirm its uniqueness not only in Ukrainian but also in general civilisational, spiritual and cultural contexts.

Methodological vectors of research are as follows: the historical and cultural method is imperative for the study of the laws of the Bandura performing genre development; the historical and logical method is for the analysis of scientific literature on the chosen problem, building the logic of comparing traditional and New Bandura performing forms; the empirical method is for the study of the main ways of forming the Bandura sound, identifying the top issues of Bandura performance in modern musical fields, the development of effective mechanisms for promoting modern Bandura performing forms.

In their works, contemporary players turn to the main origins of ethic culture (dumas, historical songs, etc.) and rethink the expressive means of 
folk melodies referring to the everlasting primary sources at a new level, to the archaic song traditions of their people, while actively developing academic pop-rock-jazz directions actively attracting sonorous, colouristic elements to the sound-forming performing complex.

Bandura Studies provides term "academic bandura", which requires very thoughtful analysis and description of the following positions: the wording of definitions "folk instrument", "academic folk instrument", "traditional folk instrument", determining the degree and depth of "nationality" and "academic" of modern Bandura performance; setting the boundaries of the required modification of both instrument and performing technique, definitions, forms and genres, performing types of training and identifying ways to preserve bandura art as a unique domain of the art culture of Ukraine.

\section{REFERENCES}

1. Broiako N. (2015) Aktualni problemy suchasnoho muzychnoho vykonavstva [Actual problems of modern musical performance]. Bulletin of Mariupol State University. Series: Philosophy, culture studies, sociology, vol. 9., pp. 33-38.

2. Dutchak V. (2013) Bandurne mystetstvo ukrainskoho zarubizhzhia $X X$-pochatku XXI stolittia [Bandura Art of Ukrainian Abroad of XX-Early XXI Century]. Ivano-Frankivsk: Foliant. (in Ukrainian)

3. Dutchak V. (2018) Tvorcha i naukova diialnist Andriia Horniatkevycha (Kanada) v konteksti rozvytku bandurnoho mystetstva Ukrainy ta diaspory [Artistic and scientific activity of Andrij Hornjatkevyč (Canada) in the context of bandura art development in Ukraine and among diaspora]. Bulletin of Kyiv National University of Culture and Arts. Series in Musical Art, vol. 1, pp. 106-124. https://doi.org/10.31866/26167581.2.2018.153383

4. Hrytsa S. (2000) Folklor u prostori ta chasi [Folklore in space and time] (ed. Smoliak O. S.). Ternopil: Aston. (in Ukrainian)

5. Hrytsa S., Ivanytskyi A., Filatova, A. (comps.) (2007) Ukrainski narodni dumy [Ukrainian folk dumas] (ed. Skrypnyk H.). Kyiv: Rylsky Institute of Art Studies, Folklore and Ethnology of National Academy of Sciences Ukraine. (in Ukrainian)

6. Humeniuk T. (2019) Kultura pochatku tretoho tysiacholittia: dyskurs novoho svitovidchuttia [The Culture of the Beginning of the Third Millennium: The discourse of a New Attitude]. National Academy of Managerial Staff of Culture and Arts Herald, no 2, pp. 8-11.

7. Khai M. (2015) Mykola Budnyk i kobzarstvo [Mykola Budnyk and kobzarism]. Lviv: Astorliabiia. (in Ukrainian)

8. Khai M. (2016) Hibrydna terminolohiia v ukrainskomu "bandura"kobzaroznavstvi [Hybrid terminology in Ukrainian "bandura" - Hybrid 
terminology in Ukrainian "bandura" - kobza studies]. Proceedings of the Tradytsiina bandura: mynule, suchasne, maibutnie: Internetional Scientific and Practical Conference (Kyiv, Ukraine, June 18-19, 2016). Kyiv: Ivan Honchar Museum, pp. 165-178.

9. Khotkevych H. (2009) Bandura ta yii repertuar [Bandura and its repertoire] (ed. Mishalov V.). Toronto ; Kharkiv: The Hnat Khotkevych Foundation for National Cultural Initiatives. (in Ukrainian)

10. Koskin V. Roman Hrynkiv: "Pro banduru maie znaty ves svit" [Roman Grinkiv: "The whole world should know about the bandura"]. Retrieved from: http://www.vox.com.ua/data/osnovy/2007/04/27/romangrynkiv-pro-banduru-maye-znaty-ves-svit.html (accessed 5 October 2020).

11. Kushpet V. (2007) Startsivstvo: mandrivni spivtsi-muzykanty $v$ Ukraini (XIX - pochatok XX stolittia) [Old age: itinerant singers-musicians in Ukraine (XIX - early XX century). Kyiv: Tempora. (in Ukrainian)

12. Mishalov V. (2013) Kharkivska bandura [Kharkiv bandura]. Kharkiv : Savchuk O. O. (in Ukrainian)

13. Nudha H. (1998) Ukrainska duma i pisnia v sviti [Ukrainian thought and song in the world] (Vol. 2). Lviv: The Ethnology Institute of National Academy of Sciences of Ukraine. (in Ukrainian)

14. Rudnytskyi A. (1963) Ukrainska muzyka [Ukrainian music]. Munich: Dniprova khvylia. (in Ukrainian)

15. Shtokalko Z. (1992) Kobzarskyi pidruchnyk [Kobzar textbook] (ed. Horniatkevych A.). Edmonton ; Kyiv: Canadian Institute of Ukrainian Studies. (in Ukrainian)

16. Yaremko B. (2003) Etnoinsturmentoznavstvo [Ethnoinstru-
[ mentology]. Rivne: Rivne State University for the Humanities. (in Ukrainian)

17. Yesypok V. (2017) Suchasne kobzarstvo [Contemporary kobza art]. Young Scientist, no 7(47), pp. 71-75.

18. Yusypei R. (2006) "Farbotony" ["Pharbotones"]. Den [Day], no 118. Retrieved from: https://day.kyiv.ua/uk/article/kultura/farbotoni (accessed 5 October 2020).

19.Zemtsovskiy I. (1977) Narodnaya muzyka i sovremennost' [Folk music and modernity]. Sovremennost' $i$ fol'klor [Modernity and folklore]. Moscow: Muzyka, pp. 28-75.

Information about the author:
Broiako Nadiia
orcid.org/0000-0001-9109-1734
PhD in Arts, Professor Kyiv National University of Culture and Arts 36, Ye. Konovaltsia St., Kyiv, 01133, Ukraine 